\title{
JIMMBA
}

Jurnal Ilmiah Mahasiswa Manajemen, Bisnis dan Akuntansi

Homepage: http://journal.stieputrabangsa.ac.id/index.php/jimmba/index

\section{Pengaruh Ukuran Perusahaan Terhadap Audit Delay Dengan Return On Asset Sebagai Variabel Mediasi Pada Sub Sektor Perbankan Tahun 2017-2018}

\author{
Verawaty Caroline ${ }^{1}$, Francis Hutabarat ${ }^{2}$ \\ 1 Universitas Advent Indonesia \\ 2Universitas Advent Indonesia \\ Email: verawatycaroline17@gmail.com
}

\section{ARTICLE INFO}

Article History:

Received: July $27^{\text {th }} 2020$

Accepted: August $1^{\text {st }} 2020$

Published: August $31^{\text {st }} 2020$

Keywords:

Audit Delay, Ukuran

perusahaan, ROA

\begin{abstract}
Adapun tujuan dari penelitian ini di adakan ialah untuk mengetahui pengaruh ukuran perusahaan terhadap audit delay dengan return on asset sebagai variable mediasi pada sub sektor perbankan tahun 2017-2018. Penelitian ini menggunakan analisis descriptive dengan menggunakan aplikasi SPSS. Adapun sampel diambil dari 15 perusahaan sub sektor perbankan yang terdaftar di BEI pada tahun 2017-2018. Penelitian memanfaatkan Ukuran Perusahaan sebagai variable independen, Audit Delay sebagai variabel dependen serta Return On Asset sebagai variabel mediasi. Penelitian ini menggunakan analisis statistic data yaitu descriptive statistic, koefisien determinasi, signifikan test dan regresi analisis. Ukuran perusahaan dan audit delay berpengaruh signifikan pada perusahaan sector perbankan yang terdaftar di BEI pada tahun 2017-2018, diperkuat oleh Roa sebagai mediasi maka hasil signifikansi ukuran perusahaan terhadap audit delay semakin tinggi. Sedangkan untuk ROA juga memiliki hubungan signifikan dengan Audit Delay.
\end{abstract}

\section{Pendahuluan}

Salah satu hal terpenting yang berperan untuk menilai kinerja perusahaan dan juga menilai ukuran perusahaan adalah laporan keuangan. Dalam SFAC No.2 dijelaskan bahwa laporan keuangan harus memiliki karakteristik yang telah di tetapkan seperti andal; relevan; material ; ada penilaian costs-benefit ; serta memiliki pembanding dan konstan agar bermanfaat bagi penggunanya. Adapun laporan keuangan dibuat dengan tujuan mengkomunikasikan informasi-informasi terkait perubahan posisi keuangan dalam satu siklus akuntansi, menilai kinerja perusahaan dalam satu periode akuntansi, serta menampilkan sumber daya milik 
perusahaan seperti manusia maupun modal serta kekayaan intangible asset nya kepada pihak internal maupun eksternal seperti investor dan pemerintah.

Tidak hanya menampilkan besarnya laba namun waktu penyajian laporan keuangan juga berpengaruh terhadap manfaat informasi yang di sajikan kepada investor dalam mengambil keputusan karena semakin lama laporan keuangan di terbitkan maka dapat di artikan oleh pihak luar/investor bahwa perusahaan memiliki kinerja buruk dengan laba yang kecil namun memiliki tingkat hutang yang diatas batas normal. Karenanya investor dan pasar modal menginginkan audit atas laporan keuangan sesuai standar Bapepam untuk di publikasikan, dengam demikian investor tertarik berinvestasi di perusahaan tersebut. (Shukeri \& Sherliza, 2010).

Lamanya waktu auditor untuk mengaudit laporan keuangan di bandingkan dengan waktu yang di cantumkan dalam laporan keuangan disebut juga dengan Audit Delay (keterlambatan pelaporan) (Utami, 2006). Menurut Keputusan yang dikeluarkan oleh Bapepam No. KEP346/BL/2011 untuk perusahaan Tbk laporan pertanggungjawaban perusahaan harus dibuat sesuai Standar Akuntansi Keuangan dan sudah di audit terlebih dahulu sesuai waktu yang di berikan yaitu paling lama 90 hari waktu maksimal pengauditan setelah tanggal laporan keuangan yang ingin di publikasikan untuk kemudian dapat di terbitkan untuk umum. UU RI No.8/1995 Bab XIV pasal 102 yang dibahas lebih lanjut di PP No.45/1995 Bab XII pasal 63 juga menegaskan bahwa emiten yang terlambat menyampaikan laporan keuangan seperti emiten, perusahaan publik, dan lainnya akan menerima sanksi sebesar satu juta rupiah setiap hari.

Faktor ukuran perusahaan menjadi faktor yang dapat memberi pengaruh pada audit delay (Puspitasari \& Latrini, 2014). (Widjaja, 2009) mengemukakan bahwa, sales average, total sales, dan total aset dapat menjadi barometer untuk menilai perusahaan tersebut tergolong besar atau kecil , hal ini juga dinamakan sebagai Firm Size. Perusahaan dengan aktiva yang besar biasanya mempunyai tendensi audit delay yang panjang lantaran ingin memberikan citra positive kepada investor.

Fenomena yang terjadi adalah ukuran perusahaan mempengaruhi audit delay ,adapun kasus yang menunjukkan hubungan audit delay dengan ukuran perusahaan dapat ditemui pada kasus yang di alami Wismilak Inti Makmur Group dimana perusahaan mencatatkan penurunan penjualan 10,62\% , dari Rp.760,67 miliar menjadi Rp.679,84 miliar, namun dengan adanya koreksi audit yang menyebakan audit delay PT. Wismilak, laba bersih perusahaan bertumbuh 59,81\% dari Rp.11,59 M naik menjadi Rp.18,49 miliar (Soenarso, 2018) . Hal ini menunjukkaan adanya hubungan antara audit delay dengan ukuran perusahaan (dalam kasus di atas memakai indikator penjualan) memiliki pengaruh yang cukup signifikan, Faktor lain yang juga berdampak pada audit delay adalah profitabilitas,yang dapat di ukur dengan 5 cara salah satunya ROA. 


\section{Kajian Teori dan Telaah Literatur}

\section{Ukuran Perusahaan}

(Heri, 2017) mengemukakan pengertian dari ukuran perusahaan yaitu skala untuk menentukan besar kecilnya perusaahaan, skala tersebut dapat berupa nilai total aset; nilai pasar saham ; dan lain sebagainya. (Sawir, 2004) firm size dapat di katakan sebagai determinan dari struktur yang ada pada perusahaan untuk sejumlah alasan yang berbeda. Ukuran perusahaan dapat mempengaruhi kekuatan tawar menawar dari suatu kontrak dalam perusahaan ( bargaining power). Bukan hanya itu, Ukuran perusahan juga dapat menjadi andalan perusahaan dalam mendapatkan modal baru atau suntikan dana. Firms size juga dapat di ukur dengan melihat total aktiva, jumlah pendapatan maupun besarnya modal di perusahaan tersebut. Perusahaan dengan total aset yang tinggi tentu mempunyai prospek menjanjikan dibanding perusahaan yang sebaliknya.

\section{Audit Delay}

Audit delay berarti selisih tanggal antara akhir tahun buku suatu perusahan/ akhir siklus akuntansi nya dengan tanggal penandatangan laporan keuangan yang disajikan ke public oleh emiten tersebut. Semakin lama panjang waktu audit delay maka semakin berkurang kepercayaan investor pada perusahaan tersebut. 3 parameter dalam mengklasifikasikan audit delay seperti yang di tuliskan oleh Dyer dan Mchugh (1975) dalam (Sari, 2011) adalah seperti yang ditulis dibawah ini:

1. Jarak antara tanggal berakhirnya laporan keuangan satu periode akuntansi sampai diterima oleh bursa efek laporan keuangan pendahuluannya atau yang di sebut juga preliminary lag.

2. Jarak antara tanggal berakhirnya laporan keuangan satu periode akuntansi dengan laporan auditor yang telah di tanda tangani atau yang disebut auditor's report lag

3. Jarak berakhirnya laporan pertanggungjawaban perusahaan satu periode akuntansi hingga tanggal laporan audit tersebut dapat di publikasikan oleh bursa efek atau yang disebut juga total lag.

Carslaw \& Kaplan (1991) dalam Ningsih \& Widhiyani (2015) Menyatakan bahwa perusahaan dengan laba yang kecil akan mempunyai keterlambatan pelaporan yang lebih lama dibanding perusahaan dengan laba besar , 2 hal yang menyebabkan yaitu : yang pertama, seringnya laba rendah di anggap sebagai acuan perusahaan tidak mampu mengelola aset perusahaan semaksimal mungkin, tentu ini akan berdampak buruk bagi perusahaan, maka perusahaan akan sebisa mungkin menunda waktu pengauditan, kedua, laba rendah berarti risiko bisnis yang tinggi sehingga membuat auditor berhati-hati dalam mengaudit laporan keuangan yang berdampak pada semakin lamanya proses audit dapat di berjalan. Sedangkan untuk perusahaan yang memiliki laba tinggi akan segera mempublish laporan keuangan untuk menampilkan citra yang baik untuk perusahaannya. 


\section{ROA}

Adapun penelitian yang lebih dalam mengenai Return On Asset (ROA) yaitu menurut (Martono, 2007) ROA atau sering disebut Rentabilitas Ekonomi dimaksudkan untuk memperkirakan kapabilitas perusahaan untuk mengoperasikan seluruh aktiva yang dimiliki semaksimal mungkin untuk mendapatkan profit. Dengan demikian Roa berfungsi untuk mengukur efektifitas dan efisiensi dalam perusahaan, khususnya dalam divisi penjualan dan alokasi asset, dijadikan sebagai pembanding efisiensi penggunaan modal perusahaan dengan perusahaan lain sejenis, serta dapat dijadikan sebagai kontrol dan perencanaan perusahaan di masa yang akan datang. Menurut (Keown, Martin, \& \& Petty, 2004) dan (Sutrisno, 2008) menyatakan bahwa adapun alat ukur dari ROA adalah sebagai berikut:

$$
R O A=\frac{\text { Laba Bersih }}{\text { Total Aktiva }}
$$

\section{Pengaruh Ukuran Perusahaan Terhadap Audit Delay}

Firm Size umumnya digunakan untuk mengelompokkan perusahaan sebagai perusahaan besar atau kecil berdasarkan jumlah aktiva emiten. Jika dibandingkan antara perusahaan besar dan kecil mengenai audit delay maka perusahaan dengan aktiva tinggi ukuran audit delaynya lebih kecil dibanding perusahaan aktiva rendahl, hal ini terjadi karena adanya faktor internal control yang ada di perusahaan masing-masing, perusahaan besar umumnya sudah mampu meng-hire orang lebih banyak untuk mengerjakan satu pekerjaan yang spesifik (Ningsih \& Widhiyani, 2015). penelitian (Puspitasari \& Latrini, 2014) menunjukkan bahwa antara ukuran perusahaan dan audit delay memiliki hubungan yang signifikan, pernyataan ini juga di perkuat oleh peneltian (Cahyanti, Sudjana, \& Azizah, 2016) yang menyatakan hal serupa.

\section{Pengaruh Roa Terhadap Audit Delay}

ROA adalah salah satu tolak ukur yang digunakan mengukur profitabilitas. Audit delay dan timeliness juga dipengaruhi oleh profitabilitas. ketepatgunaan komoditas, ketepatgunaan pengelolaan equity, serta ketepatgunaan penjualan juga di diukur menggunakan Return On Asset. Emiten yang memiliki Roa yang tinggi biasanya menginginkan untuk mempublish laporan keuangan sesegera mungkin kepada investor sehingga audit delay lebih pendek. (kharissa \& Saifi, 2018) Menurut penelitian (Suarsa \& Nawawi, 2018) Roa secara parsial menunjukkan pengaruh terhadap audit delay, sama hal nya dengan penelitian (Anggraeni, 2012) yang menunjukkan hal yang sama.

\section{Hipotesis}

Hipotesis dalam penelitian ini sebagai berikut:

H1 : Ukuran perusahaan dan Audit delay berpengaruh signifikan

H2 : Roa dan Audit Delay berpengaruh signifikan 


\section{Metode Penelitian}

Penelitian ini menggunakan analisis descriptive dengan sampel dari Bursa Efek Indonesia (BEI) dengan 15 perusahaan perbankan selama 2 tahun (2017-2018). Variable independent dalam penelitian ini menggunakan ukuran perusahaan sebagai $(X)$ dan audit delay sebagai variable dependent ( Y) dan menggunakan Return On Asset sebagi mediasi. Penelitian ini menggunakan analisis statistic data yaitu descriptive statistic,koefisien determinasi, siginifikan test, regresi analisis. Persamaan regresi pada penelitian ini

$$
\text { Delay }=\mathrm{B}_{0}+\mathrm{B}_{1} \text { size }+\mathrm{B}_{2} \text { Roa }
$$

Deskripsi :

$$
\begin{array}{ll}
\text { Delay } & =\text { Audit delay } \\
\mathrm{B}_{0} & =\text { Konstans } \\
\mathrm{B}_{1}, \mathrm{~B}_{2} & =\text { Coefficient } \\
\text { Size } & =\text { Firm Size } \\
\text { Roa } & =\text { Return On Asset }
\end{array}
$$

\section{Hasil dan Pembahasan}

\section{Descriptives}

Berdasarkan hasil perhitungan yang menggunakan abntuan spss menunjukkan hasil statistic descriptive pada penelitian ini terkait karakteristik variable dalam penelitian. Variabel ROA digunakan seberapa jauh perusahaan dapat menghasilkan laba. Nilai ROA pada penelitian ini bernilai min -2.83 dan nilai max 4 . ROA menunjukkan average yang baik yaitu $186 \%$ diatas standard pemerintah yaitu $5 \%$.

Audit Delay adalah lamanya waktu perusahan untuk mempubliskasikan laporan pertanggung jawabannya kepada publik. Audit Delay dalam penelitian mempunyai nilai min 14 dengan nilai max 89, mean dari audit delay ini adalah 49.9 yang berarti membutuhkan 50 hari untuk menunggu laporan audit sampai kepada tangan public, hal ini menunjukkan hasil yang bagus karena berada di bawah standard BAPEPAM yaitu 90 hari.

Firm Size adalah nilai yang dapat dipakai untuk mengukur kinerja manajemen perusahaan. Size menyandang nilai min 30.39 dan nilai max 36.15 dengan average sebesar 32.97. Semakin besar angka yang ditunjukkan maka semakin baik juga suatu perusahaan tersebut.

\section{Koefisien Determinasi}

Hasil spss menunjukkan bahwa dari model 1 didapati nilai R-Square adalah sebesar 0.392 juga berarti kontribusi ukuran perusahaan terhadap perubahan pada kinerja Audit Delay adalah sebesar 0.153. Terkait model 2, didapati bahwa dengan mediasi ROA maka didapati kontribusi Return On Asset terhadap perubahan pada Audit Delay menjadi sebesar 43.4\% 


\section{Significant Test}

Hasil uji signifikan menunjukkan bahwa pada model 1 ukuran perusahaan dan audit delay berpengaruh signifikan, dilihat dari nilai F-test 5.076 dan didapati nilai significant 0.032 pada $a=0.05$ atau $5 \%$. Sedangkan pada model 2, didapati bahwa dengan adanya mediasi ROA maka didapati ukuran perusahaan dan audit delay berpengaruh semakin significant dan signifikan yang ditemui lebih baik yaitu 0.000 pada $a=0.05$ atau $5 \%$ dengan F-test 19.234.

\section{Regression}

Hasil uji signifikan menunjukkan bahwa diantara keempat variable independent maka terlihat bahwa pada model 1 ada pengaruh dan signifikan pada variable Ukuran Perusahaan pada Audit Delay didapati signifikan sebesar 0.032 pada level signifikan 5\%. Sedangkan pada model 2, didapati dengan adanya mediasi ROA, didapati pengaruh semakin signifikan antara ROA dan Audit Delay yaitu 0.000 pada level signifikan 5\%. Dengan demikian keberadaan ROA sepenuhnya memediasi pengaruh Ukuran Perusahaan terhadap Audit Delay.

\section{Pembahasan}

\section{Pengaruh ukuran perusahaan terhadap audit delay}

Antara ukuran perusaahaan dan audit delay berhubungan signifikan, hal ini dilihat dari thitung -2,253 dengan nilai signifikan 0,032 dibawah standar 0,05. Ini berarti Hipotesa 1 diterima , penelitian (Puspitasari \& Latrini, 2014) dan (Cahyanti, Sudjana, \& Azizah, 2016) juga menyatakan ukuran perusahaan mempengaruhi audit delay secara signifikan. Penulis juga menambahkan Roa sebagai mediasi, dengan adanya Roa sebagai variable mediasi maka, ukuran perusahaan dan audit delay akan berpengaruh semakin signifikan.

\section{Pengaruh Roa terhadap audit delay}

Terdapat hubungan signifikan antara ROA dan audit delay dengan t-hitung 5,5331 dengan nilai signifikansi 0,000 dibawah standar 5\%(0,005). Ini berarti $\mathrm{H} 2$ diterima, hal ini didukung juga oleh penelitian (Suarsa \& Nawawi, 2018).

\section{Penutup dan Saran}

\section{Simpulan}

Berdasarkan penjelasan yang sudah di uraikan diatas, kemudian di peroleh simpulan bahwa, ukuran perusahaan dan audit delay berpengaruh signifikan berdasarkan uji yang telah di lakukan pada perusahaan sector perbankan yang terdaftar di BEI tahun 2017-2018, diperkuat oleh Roa sebagai mediasi maka hasil signifikansi ukuran perusahaan dan audit delay semakin kuat. Untuk Roa dan audit delay juga memiliki hubungan yang signifikan sehingga dapat di simpulkan semakin besar ukuran perusahaan dan Roa yang mewakilii perusahaan, maka semakin lama juga keterlambatan pelaporannya . 


\section{Saran}

Saran yang mampu di berikan penulis yaitu: 1.)Perusahaan perbankan menambah pengawasan atas internal control untuk ukuran perusahaan dan ROA agar audit delay tidak semakin tinggi dan tidak kehilangan kepercayaan investor; 2.) Investor dapat lebih berhatihati dalam berinvetasi di perusahaan besar karena kemungkinan audit delay tinggi sangat mungkin terjadi; 3.) Bisa mencari lebih banyak variasi variable yang dapat mempengaruhi audit delay seperti ROE, solvabilitas , klasifikasi industry dan lainnya, juga dapat bervariasi dalam memilih pendekatan uji beda yand di rasa dapat mengkonfirmasi hasil penelitian dengan sewajarnya.

\section{Referensi}

Anggraeni, P. \&. (2012). Pengaruh Karakteristik Perusahaan Terhadap Lamanya Proses Penyelesaian Audit ( Audit Delay). Jurnal Akuntansi \& Auditing, V.9(1), 31-42.

Angruningrum, S., \& Wirakusuma, M. G. (2013). Pengaruh Profitabilitas, Leverage, Kompleksitas Operasi, Reputasi KAP dan Komite Audit Delay. E-Jurnal Akuntansi Universitas Udayana, V.5 No.2, 251-270.

Cahyanti, D. N., Sudjana, N., \& Azizah, D. F. (2016). Pengaruh Ukuran Perusahaan, Profitabilitas, Solvabilitas Terhadap Audit Delay. (Studi Pada Perusahaan LQ 45 SubSektor Bank serta Property dan Real Estate yang Terdaftar di Bursa Efek Indonesia (BEI) Tahun 2010 - 2014). Jurnal Adiminstrasi Bisnis, V.38 No.1, 68-73.

Carslaw, C., \& Kaplan, S. (1991). An Examination of Audit Delay: Further Evidence from New Zealand. Acc and Business Research, 22.

Heri. (2017). Kajian Reset Akuntansi: Mengulas berbagai hasil penelitian terkini dalam bidang akuntansi dan keuangan. Jakarta: PT.Grasindo.

Keown, A. J., Martin, J. D., \& \& Petty, J. W. (2004). Manajemen Keuangan : PrinsipPrinsip dan Aplikasi Edisi Kesembilan. Jakarta: Indeks.

Keputusan Ketua Badan Pengawas Pasar Modal dan Laporan Keuangan Nomor: Kep-40/BL/2007. (n.d.).Jangka Waktu Penyampaian Laporan Keuangan Berkala dan Laporan Tahunan Bagi Emiten atau Perusahaan Publik yang Efeknya Tercatat Di Bursa Efek Indonesia dan Di Bursa Efek Negara Lain. Jakarta.: https:/ /www.Bapepam.go.id.2006

Kharissa, D., \& Saifi, M. (2018). Pengaruh Total Aktiva, Return On Asset (ROA) dan Debt To Asset Ratio (DAR) Terhadap Audit Delay (Studi pada Perusahaan LQ 45 yang Terdaftar di Bursa Efek Indonesia Tahun 20142016). Fakultas Ilmu Administrasi Universitas Brawijaya, V.58 No. 2, 171-178.

Martono, \&. H. (2007). Manajemen Keuangan. Yogyakarta: Ekonisia. 
Ningsih, I. G., \& Widhiyani, N. L. (2015). Pengaruh Ukuran Perusahaan , Laba Operasi, Solvabilitas, Dan Komite Audit Pada Audit Delay . E-Jurnal Akuntansi Universitas Udayana V.12 No.3. 481-495.

Puspitasari, K. D., \& Latrini, M. Y. (2014). Pengaruh Ukuran Perusahaan, Anak Perusahaan, Leverage dan Ukuran KAP Terhadap Audit Delay. E-Jurnal Akuntansi Universitas Udayana, V.8 No.2, 283-299.

Sari, H. C. (2011). "Analisis Faktor-faktor yang Berpengaruh terhadap Jangka Waktu Penyelesaian Audit". Universitas Diponegoro.

Sawir, A. (2004). Kebijkan Pendanaan dan Restrukturisasi Perusahaan. Jakarta : Gramedia.

Shukeri, S. N., \& Sherliza, P. N. (2010). Timeliness Of Annual Audit Report. Some Empirical Evidence From Malaysia.

Soenarso, A. (2018, agustus 1). Ada Koreksi Audit, laba bersih Wismilak Inti Makmur tercatat naik 59,81\%. Kontan. diambil dari: https://industri.kontan.co.id/news/ada-koreksiaudit-laba-bersih-wismilak-inti-makmur-tercatat-naik-5981

Suarsa, A., \& Nawawi, E. M. (2018). Pengaruh return On Asset, Debt to Asset Ratio, Dan Opini Audit Terhadap Audit Delay. Jurnal Ilmiah MEA ( Manajemen, Ekonomi,E Akuntansi), V.2 No.1, 1-9.

Sutrisno, H. (2008). Manajemen Keuangan Teori,Konsep, dan Aplikasi. Yogyakarta: Ekonisia.

Utami, W. (2006). Analisis Determinan Audit Delay Kajian Empiris di Bursa Efek Jakarta. Bulletin Penelitian. V.9 No. 1. 19-31

Widjaja, I. (2009). Pengaruh Firm Size dan Capital Structure Terhadap Prospek Saham Perusahaan. Jurnal Organisasi dan Manajemen. Th II, No. 1, 21-30. 